\title{
Melukis Masker (Berkreasi dalam Pandemi)
}

\section{Wayan Diana Putra', Ni Nyoman Sutrisna Yanthi ${ }^{2}$}

${ }^{1}$ Jurusan Pendidikan Seni Pertunjukan, ${ }^{2}$ Jurusan Desain Mode, Institut Seni Indonesia Denpasar

dianaputra@isi-dps.ac.id

Pelaksanaan KKN tahun 2020 ini dihadapkan dengan pandemi global Covid-19 yang mewabah begitu agresif. Pandemi ini tidak hanya berdampak pada aspek kesehatan namun melumpuhkan seluruh sendi-sendi kehidupan dari ekonomi, sosial, politik dan sebagainya. Mengingat jadwal pelaksanaan dari KKN Institut Seni Indonesia Denpasar jatuh pada masa pandemi maka format terjun ke lapangan dan bersosialisasi dengan masyarakat menjadi terkendala. Terkandala dari kebijakan protokol kesehatan yang menghimbau untuk meniadakan kontak dan pertemuan dalam skala besar. Namun kegiatan KKN ini mesti berjalan sesuai dengan kalender akademik yang sudah berjalan maka tahun 2020 ini LP2MPP Institut Seni Indonesia Denpasar membuat format KKN dalam jaringan (daring). Disamping dengan format daring KKN tahun 2020 dilaksanakan dalam lingkungan penulis sendiri. Oleh sebab itu proker yang diaktualisasikan ialah Melukis Masker Bagi Anak-Anak untuk mengeliatkan anak-anak di lingkungan Desa Sumerta Kelod untuk tetap berkreasi dalam pandemi. Adapun metode yang digunakan dalam program kerja (proker) melukis masker ini adalah sosialisasi, eksplorasi, pelaksanaan kegiatan melukis masker dan penyebaran masker. Pelaksanaannya meliputi dari pengajarn teknik melukis, melukis pada media masker dan menyebarkan pada aparatur desa dan masyarakat sekitar yang memerlukan. Dalam proker melukis masker ini terkandung nilai-nilai yaitu nilai kreativitas dan nilai pendidikan. Nilai kreativitasnya ialah mengkreasikan imajinasi dalam seni lukis. Nilai kependidikannya ialah mengajarkan anakanak peduli dengan kesehatan melalui membagikan masker hasil dari kreasi mereka.

\section{Kata Kunci : KKN Daring, Melukis Masker, Kreativitas dan Pendidikan}

The implementation of the 2020 Community Service Program is faced with the global Covid-19 pandemic which has become so aggressive. This pandemic not only affects the health aspect but paralyzes all aspects of life from the economy, social, politics and so on. Considering that the implementation schedule of the KKN at the Indonesian Art Institute in Denpasar fell during the pandemic, the format for going into the field and socializing with the community was hampered. Disturbed by the health protocol policy which calls for eliminating contacts and meetings on a large scale. However, this KKN activity must run in accordance with the academic calendar that is already running, so in 2020 LP2MPP the Indonesian Institute of the Arts Denpasar will create an online KKN format. In addition to the online format, the 2020 Community Service Program is carried out in the author's own environment. Therefore, the actualized workshops were painting masks for children to encourage children in the village of Sumerta Kelod to continue to be creative in the pandemic. The methods used in the mask painting work program (proker) are socialization, exploration, implementation of mask painting activities and the distribution of masks. Its implementation includes teaching painting techniques, painting on mask media and distributing it to village officials and surrounding communities who need it. The mask painting program contains values, namely the value of creativity and educational value. The value of creativity is to create imagination in painting. Its educational value is to teach children to care about health by distributing masks from their creations.

Key Word: KKN Daring, Face Mask Painting, Creativity and Education 


\section{PENDAHULUAN}

Kuliah Kerja Nyata (KKN) adalah salah satu program yang dibebankan kepada mahasiswa untuk menuntaskan pendidikan jenjang Strata 1 (S1). KKN merupakan salah satu pendidikan dengan memberikan mahasiswa pengalaman belajar untuk meningkatkan kapasitas dirinya dengan cara terlibat langsung berpartisifasi aktif melakukan upaya membantu masyarakat di daerah (Tim KKN ISI Denpasar Masa Covid 19, 2020:1). Selian itu KKN juga merupakan aktualisasi nyata dari salah satu Tri Dharma Perguruan Tinggi yaitu pada bidang pengabdian. Pengabdian merupakan ruang dimana mahasiswa dapat mengamalkan kompetensinya yang didapat dari pembelajaran atau proses penelitian kepada masyarakat secara langsung. Bertemunya mahasiswa dengan masyarakat selaku stake holder disebut dengan aktualisasi. Aktualisasi merupakan serangkaian kegiatan untuk mengejawantahkan secara langsung mengenai teori-teori yang masih berbentuk abstraksi agar menjadi sebuah bentuk konkret dan dapat dirasakan langsung oleh mahasiswa.

Sesuai dengan kalender akademik yang berlaku di Institut Seni Indonesia pada awal semester ganjil kedua fakultas yang bernaung di bawahnya yaitu Fakultas Seni Pertunjukan (FSP) dan Fakultas Seni Rupa dan Desain (FSRD) melaksanakan program KKN bagi mahasiswa yang telah memenuhi syarat untuk mengambil program KKN. Program KKN di Institut Seni Indonesia Denpasar dikelola oleh LP2MPP secara teknis maupun prosedural. Program KKN di Institut Seni Indonesia Denpasar mengambil masa aktualisasi selama satu bulan penuh bekerjasama dan melayani masyarakat langsung di daerah tujuan. Dalam aktualisasinya mahasiswa membuat sebuah program kerja (proker) berbasis dengan kompetensi yang dimiliki oleh mahasiswa berkolaborasi dengan kebutuhan dari masyarakat. Dalam hal ini terjadi sebuah sinergisitas antara kompetensi mahasiswa yang diharapkan dapat membantu masyarakat mengenai kebutuhan yang ingin dipecahkan. Spirit sublimasi pengetahuan yang bersifat abstrak dalam proses ini dapat terwujud secara konkrit serta dirasakan betul dampaknya.

Pelaksanaan KKN tahun 2020 ini dihadapkan dengan pandemi global Covid-19 yang mewabah begitu agresif. Pandemi ini tidak hanya berdampak pada aspek kesehatan namun melumpuhkan seluruh sendi-sendi kehidupan dari ekonomi, sosial, politik dan sebagainya. Mengingat jadwal pelaksanaan dari KKN Institut Seni Indonesia Denpasar jatuh pada masa pandemi maka format terjun ke lapangan dan bersosialisasi dengan masyarakat menjaditerkendala. Terkandala dari kebijakan protokol kesehatan yang menghimbau untuk meniadakan kontak dan pertemuan dalam skala besar. Namun kegiatan KKN ini mesti berjalan sesuai dengan kalender akademik yang sudah berjalan maka tahun 2020 ini LP2MPP Institut Seni Indonesia Denpasar membuat format $\mathrm{KKN}$ dalam jaringan (daring). KKN daring ini secara teknis ialah tetap melakukan pengabdian kepada masyarakat namun sesuai dengan protokol kesehatan masa pandemi Covid-19. Teknisnya ialah mahasiswa melakukan kegiatan di daerah atau lingkungannya sendiri dengan memanfaatkan secara maksimal teknologi dalam jaringan (internet dan digital). Disamping itu mahasiswa peserta KKN diharapkan membuat proker secara mandiri dengan mendayagunakan kompetensinya seninya masingmasing dalam membantu pencegahan penyebaran virus Covid-19.

Dengan sistem daring dan proker individu yang diharapkan dapat membantu pencegahan penularan virus Covid-19 maka munculah proker melukis masker, membatik masker serta mengajarkan anak-anak menggambar dengan idiom-idiom edukasi pencegahan virus Covid-19. Melukis masker melibat anak-anak dengan tujuan memberikan ruang kreativitas dan berbagi dalam masa pademi. Membatik masker mengasah kesabaran anak-anak dalam menghadapi pandemi Covid-19 lewat teknik membatik. Mengajarkan anak-anak mengambar masker secara tidak langsung mengaktualisasikan himbauan protokol kesehatan sebagai media sosialisasi pencegahan virus Covid-19 pada anakanak. Proker tersebut dilakukan mengikuti standar protokol kesehatan yang ditetapkan oleh pemerintah. Serta telah mendapat persetujuan langsung dari pemangku kebijakan dari Kepala Desa Sumerta Kelod, Kecamatan Denpasar Timur, Kota Madya Denpasar. Proker melukis masker ialah aktivitas berkreasi serta edukasi di dalam masa pademi, serta hal ini menunjukkan kreativitas seni tidak dapat dipasung oleh wabah pandemi global virus Covid-19 yang telah meluluhlantakkan sendi-sendi kehidupan.

\section{METODE PELAKSAANAAN}

Pelaksanaan proker melukis masker yang dilakukan 
dalam rangka program KKN Institut Seni Indonesia Denpasar tahun 2020 di Desa Sumerta Kelod, Denpasar dilakukan dengan empat tahapan yaitu 1) Sosialisasi, 2) Observasi, 3) Proses Melukis dan 4) Penyebaran Masker. Keempat tahapan tersebut merupakan rancangan proses kegiatan yang mengarahkan untuk mewujudkan sasaran yang dituju.

\section{Sosialisasi}

Sosialisasi merupakan tahapan pertama yang dilakukan setelah memantapkan proker melukis masker pada anak-anak untuk program KKN Institut Seni Indonesia Denpasar tahun 2020 di Desa Sumerta Kelod, Denpasar. Pada tahap sosialisasi ini penulis mendatangi Kantor Kepala Desa Sumerta Kelod untuk melapor diri serta memohon izin agar diberikan izin serta legalisasi untuk dapat melaksanakan kegiatan melukis masker bagi anakanak di lingkungan Desa Sumerta Kelod.

Dengan menyertakan surat penghantar dari lembaga dalam halinidari Panitia KKNDaring Tahun 2020 oleh LP2MPP Institut Seni Indonesia Denpasar dengan nomor: 427/IT5.3/PM/2020, kami menghadap Kepala Desa serta menjelaskan maksud dan tujuan hingga rancangan proker melukis masker pada anakanak. Hasil dari pertemuan itu ialah keluarnya surat ijin rekomendasi pelaksanaan proker melukis masker pada anak-anak dengan surat nomor: 427/250/ VII/2021 dengan beberapa catatan yang harus kami taati yaitu 1) Dilarang melakukan kegiatan di luar daripada kegiatan tujuan yang telah ditetapkan, 2) Para peneliti, survey, studi perbandingan, KKL, KKN mentaati dan menghormati ketentuan yang berlaku, dan 3) Tetap mengikuti protokol kesehatan yaitu jaga jarak, memakai masker dan selalu cuci tangan.

Setelah melengkapi dan mengikui prosedur administrasi yang berlaku dengan berbekal surat izin rekomendasi dari Kepala Desa maka hal ini memantapkan langkah penulis untuk melaksanakan program selanjutnya. Program selanjutnya kami ialah melakukan tahapan eksplorasi. Eksplorasi terhadap situasi lingkungan dan situasi masyarakat terlebih di masa pandemi Covid 19 maka penulis melakukannya denga secermat mungkin agar tidak sampai melanggar dari catatan yang diberikan oleh Kepala Desa yang tertuang dalam surat izin rekomendasinya.

Kendala yang dihadapi pada tahap sosialisasi ini ialah penulis tidak dapat terjun secara luas dilapangan mengingat pandemi Covid 19 yang sedang mewabah. Hal ini sangat menyulitkan ruang gerak penulis untuk mencari peserta anak-anak dalam jumlah yang lebih banyak serta tidak leluasa untuk menjelaskan gagasan dari proker yang penulis lakukan.

\section{Eksplorasi}

Pada masa eksplorasi penulis melakukan dua bentuk kegiatan yaitu 1) Memantau dan mengecek situasi masyarakat di Desa Sumerta Kelod dan 2) Memilih anak-anak yang akan dijadikan peserta dari proker melukis masker. Kedua kegiatan tersebut saling terkait, kegiatan pertama dalam memantau situasi lingkungan Desa Sumerta Kelod adalah untuk mendapat data daerah-daerah yang aman untuk mengambil peserta anak-anak nantinya yang akan disertakan dalam proker melukis masker. Dengan mengetahui keadaan dan situasi lingkungan maka memudahkan untuk mencari serta memilih anakanak yang akan diikut sertakan pada program melukis masker.

Pada tahapan ini penulis sangat dibantu oleh aparatur kantor desa untuk memilih peserta anakanak. Bantuan dari aparatur kantor desa ini sangat signifikan sekali dalam membantu proses mencari peserta anak-anak, mengingat ruang gerak penulis dibatasi oleh situasi pandemi covid 19. Dari aparatur kantor desa penulis mendapatkan peserta anak-anak yang aman dan pemilihannya sudah sesuai protokol kesehatan.

Setelah mendapatkan peserta anak-anak selanjutnya dalam observasi ini penulis melakukan pemantauan mengenai karakteristik dari tiap-tiap anak-anak unuk menentukan motode pelatihan melukis masker. Setelah melakukan observasi ditemukan karakteristik dari peserta anak-anak tidak semuanya memiliki kemampuan melukis yang bagus, sehingga perlu untuk diberikan proses pelatihan dasar terlebih dahulu. Adapaun perserta anak-anak yang didapat pada proker ini berjumlah 5 orang yang diambil dari siswa dari SD Negeri 7 dan SD Negeri 9 Sumerta.

Kendala yang penulis hadapi pada tahap eksplorasi ialah bertemu dan bersosialisasi dengan masyarakat dengan lebih luas sesuai dengan Keputusan Menteri Kesehatan Republik Indonesia Nomor: HK.01.07/ Menkes/382/2020 Tentang Protokol Kesehatan Bagi Masyarakat di Tempat dan Fasilitas Umum Dalam Rangka Pencegahan dan Pengendalian 
Corona Virus Disease 2019 (Covid 19). Sebelum terjadinya pandemi ini pelaksanaan aktualisasi proker KKN dilakukan dengan melibatkan banyak orang, namun sesuai dengan peraturan pemerintah melalui Kemenkes dalam surat tertera di atas harus membatasi partisipasi peserta. Merujuk dari hal itu maka peserta proker dari melukis masker ini hanya melibatkan peserta enam sampai sepuluh orang saja. Kedua, mengingat ruang gerak penulis dalam aktualisasi proker maka diperlukan teknik-teknik yang efisien agar capain proker dapat terwujud. Salah satunya memberikan peserta pelatihan dasar sebelum memulai proses melukis masker dengan media kain dengan cara mengajak peserta untuk memulai melukis pada media kertas terlebih dahulu. Pelatihan dasar melukis pada media kertas dilakukan mengingat dari segi tekstur melukis pada media kertas lebih mudah daripada melukis pada media kain. Dapat juga dijelaskan pada tahap eksplorasi ini penulis mengajak salah satu anak dari peserta yang telah ditetapkan untuk proses pengenalan. Dalam proses ini anak tersebut diajak melakukan kegiatan melukis guna mengetahui metode dan materi seperti apa yang akan diterapkan dalam proses pengajarannya. Hal penting yang penulis dapatkan pada proses pengenalan ini ialah anak tersebut belum mampu mengenai tata cara mencampur air dan cat, teknik membersihkan kuas dan mencampur warna.

\section{Proses Melukis}

Pelaksanaan proker melukis masker bertempat di Kantor Desa Sumerta Kelod, Kecamatan Denpasar Timur, Kota Madya Denpasar. Dipihnya Kantor Desa Sumerta Kelod sebagai tempat pelaksanaan proker melukis masker ini mengingat prosedur pemilihan lokasi proker dalam masa pandemi Covid 19 dilakukan pada lingkungan tempat tinggal penyelenggara proker sendiri (penulis kedua). Dalam pelaksanaan teknisnya, pihak dari Kantor Desa Sumerta Kelod memberikan penulis ruangan perpustakaan yang berada dalam kantor desa.

Tahap awal dari pelaksanaan proker melukis masker ini adalah penulis membuat masker yang kemudian dilukis oleh para peserta anak-anak. Masker dibuat sendiri oleh penulis kedua berbahan kain. Setelah menyelesaikan masker yang selesai dibuat, selanjutnya penulis menyiapkan alat-alat melukis. Setelah itu penulis merancang untuk latihan melukis pada media kertas terlebih dahulu sebelum melukis pada media masker kain.

Sebelum memulai tahap latihan melukis pada kertas, penulis menyipakan materi berupa sktesa gambar yang diajarkan pada peserta. Latihan melukis pada media kertas bertujuan untuk memberikan pengenalan tentang teknik membuat sketsa dan kemudian mewarnai. Pada tahapan ini proses pelatihan berjalan dengan lancer dan para peserta dengan cepat memahami materi yang penulis berikan. Setelah beberapa kali melakukan latihan melukis pada media kertas dan setelah penulis amati hasilnya yang sudah cukup bagus, maka kemudian para peserta siap untuk diberikan masker kain untuk dilukis sesuai dengan kreasinya. Para peserta diberikan masing-masing dua buah masker untuk dilukis.

Pada proses melukis masker bermedia kain, penulis mengarahkan peserta untuk menuangkan imajinasi serta kreasinya dengan memulai membuat sketsa dari bentuk atau gambar yang diinginkan. Setelah menyelesaikan sketsa penulis mengamati hasil sketsa dari masing-masing peserta sebelum lanjut untuk diwarnai dengan cat. Cat yang digunakan adalah jenis cat air. Digunakan cat air ialah untuk memudahkan peserta anak-anak untuk mencampur warna dan membersihkannya. Terkadang penulis memberikan koreksi atau evaluasi dari hasil sketsa yang telah terbentuk. Setelah sketsa dirasakan cukup sesuai dengan keinginan dan proporsinya jelas, maka selanjutnya dilakukan proses pewarnaan.

Adapun tabel pelaksanaan proker melukis masker ini dapat disimak pada tabel di bawah ini:

\begin{tabular}{cl}
\hline \multicolumn{1}{c}{ Tanggal } & \multicolumn{1}{c}{ Kegiatan } \\
\hline 1 Agustus 2020 & $\begin{array}{l}\text { Sosialisai dengan pihak Kepala Desa } \\
\text { Sumerta Kelod untuk menjelaskan } \\
\text { program kerja melukis masker }\end{array}$ \\
\hline 2 Agustus 2020 & Mempersiapkan alat-alat melukis \\
\hline 3 Agustus 2020 & Membuat masker \\
\hline 4 Agustus 2020 & Membuat masker \\
\hline 5 Agustus 2020 & Observasi materi untuk mengajar \\
& dasar-dasar melukis \\
\hline 6 Agustus 2020 & $\begin{array}{l}\text { Menyiapkan materi untuk mengajar } \\
\text { dasar-dasar melukis }\end{array}$ \\
\hline 7 Agustus 2020 & Mencetak materi dan gambar yang \\
& telah dipersiapkan \\
\hline 8 Agustus 2020 & Melakukan survey di perpustakaan \\
& kantor desa \\
\hline 10 Agustus 2020 & pelaksanaan proker \\
\hline & Latihan menggambar \\
\hline & Latihan menggambar \\
\hline & \\
\hline &
\end{tabular}




\begin{tabular}{cl}
\hline 11 Agustus 2020 & $\begin{array}{l}\text { Memotong kain untuk membuat } \\
\text { masker tahap 2 }\end{array}$ \\
\hline 12 Agustus 2020 & Membuat masker tahap 2 \\
\hline 13 Agustus 2020 & Mulai mengajar mewarnai masker \\
\hline 14 Agustus 2020 & Proses mewarnai masker \\
\hline 21 Agustus 2020 & Proses mewarnai masker \\
\hline 23 Agustus 2020 & Packing masker untuk dibagikan \\
\hline 27 Agustus 2020 & $\begin{array}{l}\text { Membagi masker ke perangkat desa } \\
\text { dan warga yang memerlukan }\end{array}$ \\
\hline
\end{tabular}

Penyebaran Masker

Setelah selesai dilukis maka selanjutnya penulis mengajak peserta untuk mengkemas masker yang telah jadi untuk disebarkan. Selain masker yang telah dilukis digunakan sendiri oleh peserta, satunya lagi disebarkan pada perangkat desa dan warga lain yang dipilih oleh peserta.

Anak-anak yang ikut melaksanakan pembagian masker bersama, sebelumnya telah bergabung dalam satu kelompok/organisasi perpustakaan Desa Sumerta Kelod dan cukup aktif dalam kegiatankegiatan yang dilakukan oleh pengelola perpustakaan kantor desa. Mereka tertarik melakukan pembagian bersama dikarenakan mereka ingin mencoba sesuatu sambil bermain bersama.

\section{Nilai Gagasan yang Terkandung}

Dalam aktualisasi proker melukis masker ini terdapat dua gagasan pokok yaitu kreativitas dan pendidikan. Kreativitas dan pendidikan adalah dua elemen yang harus dipupuk untuk mewujudkan kemajuan bangsa. Walaupun dalam masa pandemi Covid 19 kreativitas dan pendidikan tidak boleh terhenti apalagi mati. Dalam situasi apapun kedua elemen ini harus bergeliat, oleh sebab itu proker melukis masker ini di dalamnya terkandung nilai kreativitas dan pendidikannya. Nilai kreativitasnya dapat dilihat dari bagaimana anak-anak dapat mengembangkan dan mencurahkan imajinasinya dalam bentuk kreasi lukisan pada masker. Kedua, nilai pendidikanmerunya ialah memberikan anakanaknya pentingnya taat terhadap protokol kesehatan dengan memproduksi alat pelindung dirinya seperti masker. Secara tidak langsung mereka diajak untuk sadar terhadap pentingnya penggunaan masker pada masa pandemi melalui kegiatan melukis masker.

\section{Nilai Kreativitas}

Seorang sastrawan handal Putu Wijaya yang menyatakan:" Kreativitas juga ketepatan untuk memilih nuansa-nuansa itu sendiri secara akurat, sehingga tercipta sesuatu yang baru, segar dan membudayakan (Iswantara, 2017:9). Koentjaraningrat (1987:256) sikap dalam mengembangkan penemuan-penemuan baru atau menciptakan karya baru adalah kesadaran para individu akan kekurangan dalam kebudayaan dan sistem perangsang dari aktivitas pencipta dalam masyarakat. Proker melukis masker merupakan sebuah tindakan baru pada masa pandemi untuk dapat menyalurkan imajinasi seni lukis pada alat pelindung diri berupa masker.

Kreativitas dalam proker melukis masker dapat dilihat pada dua dimensi yaitu 1) Dari dimensi penulis sebagai perancang proker dan 2) Dari dimensi pesertanya. Pertama dari sisi penulis proker melukis dengan masker adalah pemilihan gagasan yang dilandasi oleh kreativitas. Kreativitas membaca isu yang sedang berkembang dan bergulir hangat. Dalam masa pandemi Covid 19 segala aktivitas seni terpasung dan kehilangan ruang/panggung untuk demonstrasi gagasan atas kekaryaannya. Oleh sebab itu memilih masker sebagai obyek untuk tetap berkreativitas khususnya dikolaborasikan dengan seni lukis. Maka munculah gagasan melukis masker pada anak-anak. Pemilihan anak-anak dilatarbelakangi oleh penulis mengamati selama pandemi ini anak-anak mudah bosan dengan kegiatan karantina mandiri yang diberlakukan. Mereka yang biasanya banyak kegiatan mendadak harus berdiam diri. Oleh sebab itu maka penulis memilih anak-anak sebagai peserta dari kegiatan proker melukis masker tentunya dengan menerapkan protokol kesehatan yang telah digariskan oleh pemerintah.

Kedua, dari peserta anak-anak sendiri mereka mendapatkan ruang untuk berkreativitas dengan mencurahkan imajinasinya pada masker. Hal ini sangat diinginkan oleh anak-anak mengingat mereka setelah beberapa bulan harus berdiam diri di rumah. Kesempatan ini mereka gunakan untuk menyegarkan suasana hati mereka. Mereka keluar sejenak dari kepenatan dan ketakutan mereka dengan pandemi Covid 19 dengan bermain imajinasi dan warna dalam aktivitas melukis. Kreativitas mereka yang selama masa karantina mandiri sempat terpasung seakan mendapat ruang berinteraksi kembali walaupun dengan segala keterbasannya.

Dalam berita elektronik yang diunggah pada media elektronik oleh Media Indonesia tanggal 17 Juni 2020 pukul 00.58 WIB yang ditulis oleh Atikah 
Ishmah Winahyu. Atikah menulis: "Menurut seniman teater Herlina Syarifudin mengungkapkan ada beberapa dampak positif yang dialaminya dalam masa pandemi. Pertama, kepedulian sesama seniman untuk saling bekerja sama semakin terasa. Krisis Covid 19 membuat seniman saling merangkul satu sama lain. Berita ini kemudian memantik penulis untuk melakukan kegiatan melukis masker oleh anak-anak, sehingga dari aktivits bekesenian melukis dapat membantu orang lain dalam hal memberikan alat pelindung diri berupa masker yang telah dilukis.

Nilai Pendidikan

Pendidikan merupakan suatu proses yang diperlukan untuk mendapatkan keseimbangan dan kesempurnaan dalam perkembangan individu maupun masyarakat. Pendidikan dalam bahasa Yunani berasal dari kata pedagogik yaitu ilmu menuntun anak. Bangsa Jerman melihat pendidikan sebagai Erziehung yang setara dengan educare yakni membangkitkan kekuatan terpendam atau mengaktifkan kekuatan potensi anak (Nurkholis, 2013:2). Pendapat lain tentang pendidikan dikemukan oleh Begawan pendidikan bangsa ini yaitu Ki Hajar Dewantara yang menyatakan: "Pendidikan adalah tuntunan di dalam tumbuh kembangnya anak-anak, yakni menuntun segala kekuatan yang ada pada anak-anak berupa potensi agar mereka sebagai manusia dan sebagai anggota masyarakat dapat mencapai keselamatan dan kebahagiaan setinggi-tingginya (Hidayat, 2013:1).

Nilai pendidikan dari proker melukis masker ini adalah selain mengajarkan teknik-teknik melukis pada anak-anak juga mengajarkan kepekaan. Kepekaan serta kepedulian terhadap situasi yang terjadi pada lingkungan sekitar. Seperti dalam masa pandemi Covid 19 kepedulian untuk menjaga diri dan orang lain agar tetap sehat merupakan prioritas utama. Memakai masker merupakan protokol dasar pada masa pandemi Covid 19 untuk melindungi diri dan orang lain dari penularan virus ini. Himbauan mengenai penggunaan masker semenjak pandemi Covid 19 ini mewabah telah dilakukan secara massif dalam bentuk peraturan, iklan pada media sosial, poster maupun baliho. Namun proker melukis masker ini mengajak anak-anak untuk dapat meproduksi masker secara madiri dan juga untuk dirinya sendiri. Dengan mengajan mereka melukis masker sesuai dengan kreativitasnya sendiri diharapkan ketaatan dalam menggunakan masker dapat meningkat.
Disamping itu diakhiri program melukis masker ternyata terdapat kelebihan produksi sehingga memungkinkan untuk membagikan kepada orang lain. Dalam hal ini program ini tidak saja mengedukasi peserta saja untuk menghasilkan masker secara mandiri tetapi juga dapat berkontribusi dengan orang lain dengan membagikan masker yang telah dilukis bagi orang lain yang memerlukan. Sampai proses ini jadi kepekaan atau kepedulian terhadap kesehatan diri sendiri dan orang lain dalam mencegah penularan virus Covid 19 dapat diwujudkan. Sejalan dengan apa yang diutarakan oleh Ki Hajar Dewantara dengan melukis masker anak-anak dapat mendatangkan kebahagiaan bagi dirinya sendiri dan keselamatan bagi orang lain dengan memberikan masker pada masa pandemi ini.

\section{KESIMPULAN}

Proker melukis masker ini merupakan sebuah aktualisasi pengabdian penulis sesuai dengan yang diamanatkan dalam Tri Dharma Perguruan Tinggi salah satunya pada bidang pengabdian. KKN merupakan wadah untuk aktualisasi dari pengabdian tersebut. Proker melukis masker tidak saja sebagai wujud pengabdian antara insan akademik dengan stake holder, melainkan juga sebagai wujud penyemaian kembali kreativitas dalam masa pandemi yang sempat terkungkung. Melalui proker melukis masker dapat dibuktikan jika dalam masa pandemi kreativitas tidak boleh terhenti.

\section{DAFTAR RUJUKAN}

Desa Sumerta Kelod. 2018. Profil Desa Sumerta Kelod, Kecamatan Denpasar Timur, Kota Denpasar. Denpasar: Kantor Desa Sumerta Kelod.

Hidayat, Syarif. 2013. Teori dan Prinsip Pendidikan. Tanggerang: PT. Pustaka Mandiri

Iswantara, Nur. 2017. Kreativitas : Sejarah, Teori \& Perkembangan. Yogyakarta: Gigih Pustaka Mandiri.

Koentjaraningrat. 1987. Sejarah Teori Antropologi I. Jakarta : PT. Gramedia.

Nurkholis. 2013. Pendidikan Dalam Upaya Memajukan Teknologi, dalam Jurnal Kependidikan, Vol.1 No. 1. Purwokerto : IAIN Purwokerto. 
Tim Panitia KKN ISI Pada Masa Covid 19. Panduan dan Petunjuk Teknis (Juknis) Pelaksanaan KKN ISI Pada Masa Covid 19. Denpasar: LP2MPP ISI Denpasar

Winahyu, Atikah Hismah. 2020. Seniman Mengasah Kreativitas di Tengah Pandemi, Sebuah Artikel Humaniora dalam media elektronik mediaindonesia. com. Jakarta: Media Indonesia. 